\title{
Country size and trade in intermediate and final goods ${ }^{*}$
}

\author{
Kwok Tong Soo ${ }^{\dagger}$ \\ Lancaster University
}

May 2017

\begin{abstract}
This paper documents a negative relationship between country size and the share of final consumption goods in total exports. A model is developed, based on the division of labour and comparative advantage, to explain this relationship. Labour is used to produce traded intermediate inputs which are used in the production of traded final goods. Large countries gain relatively more from comparative advantage than from the division of labour, while the opposite is true for small countries. As in the data, large countries export a smaller share of final goods and a larger share of intermediate goods than small countries. It is shown that the model developed in the paper yields the same results as a model based on monopolistic competition.
\end{abstract}

JEL Classification: F11.

Keywords: Country size; division of labour; comparative advantage; gains from trade; intermediate goods trade.

\footnotetext{
* An earlier version of this paper was previously circulated as "Trade in intermediate goods and the division of labour". Thanks to the editor, Chris Milner, and two anonymous referees for valuable comments and suggestions. The author is responsible for any errors and omissions.

† Department of Economics, Lancaster University Management School, Lancaster LA1 4YX, United Kingdom. Tel: +44(0)1524 594418. Email: k.soo@lancaster.ac.uk
} 


\title{
Country size and trade in intermediate and final goods
}

\begin{abstract}
This paper documents a negative relationship between country size and the share of final consumption goods in total exports. A model is developed, based on the division of labour and comparative advantage, to explain this relationship. Labour is used to produce traded intermediate inputs which are used in the production of traded final goods. Large countries gain relatively more from comparative advantage than from the division of labour, while the opposite is true for small countries. As in the data, large countries export a smaller share of final goods and a larger share of intermediate goods than small countries. It is shown that the model developed in the paper yields the same results as a model based on monopolistic competition.
\end{abstract}

JEL Classification: F11.

Keywords: Country size; division of labour; comparative advantage; gains from trade; intermediate goods trade. 


\section{Introduction}

The recent rise of China has been associated with its (re-)integration with the world trading system. In some circles, China is now known as the "factory of the world", producing a large proportion of the world's manufactured goods (see for example The Economist (2015)). A concurrent trend has been the increasing fragmentation of production, as final goods are assembled from intermediate inputs which themselves are produced in different parts of the world (Jones (2000)). The article in The Economist cited above suggests a link between China's rise and its role in the global value chain. Nevertheless, Hsieh and Ossa (2016) find only small effects on real income in the rest of the world, of China's productivity increase since the mid-1990s.

There is of course a large theoretical and empirical literature on the importance of intermediates trade. The theoretical side has been dominated by models of monopolistic competition and economic geography (see the synthesis provided by Helpman and Krugman (1985) and Fujita et al (1999)). On the empirical side, Miroudot et al (2009) and Sturgeon and Memedovic (2010) show that intermediate inputs represent over half of total goods trade, but that this fraction has actually decreased since the 1960s. Implicit in the discussion about the role of China in the world trading system is the effect of China's size. The role of country size in determining the importance of intermediate goods trade has not heretofore been discussed in the literature, and is the main focus of the present paper.

Divide all commodities into consumption goods and intermediate goods (where goods are classified according to the Broad Economic Categories (BEC) classification; more details are in Appendix A). Figure 1 shows that, in 2012, there is a negative relationship between the share of consumption goods in total exports, and the size of the economy as measured by real GDP. That is, on average, a larger country exports a larger fraction of intermediate goods, and a smaller fraction of consumption goods. The correlation coefficient is -0.3008 , with a p-value of 0.0005 . Note that both China and India are outliers; they have much larger shares of consumption goods in their exports than would be predicted given their size. More formal econometric evidence using a panel of 170 countries from 1995 to 2014 is presented in Appendix A, and supports the results of Figure 1.

The objective of this paper is to develop a simple theoretical model to explain the negative relationship between country size and the share of consumption goods trade. 
Two final goods can be produced using intermediate inputs which are produced using labour as the only factor of production. As in Adam Smith (1776), the more the production process can be divided into different stages, the larger will be the final output. The division of labour is combined with Ricardo's (1817) comparative advantage, so that countries specialise in different subsets of intermediate goods, then trade both intermediate and final goods. We show two main results. First, we show the relationship between the division of labour and comparative advantage in international trade. Large countries gain relatively more from comparative advantage than from the division of labour, while the opposite is true for small countries. Second, and consistent with the empirical evidence, country size is negatively associated with the share of consumption goods in its exports (equivalently, is positively associated with the share of intermediate goods in its exports).

There has been a recent resurgence of interest in models of international trade based on the division of labour. A large portion of this literature revolves around models based on external scale economies, for instance Grossman and Rossi-Hansberg (2010) and Ethier and Ruffin (2009). Choi and Yu (2003) survey the earlier literature on international trade under external scale economies. Relative to this literature, the present paper develops an explicit model of the division of labour, rather than basing it on external economies. Also closely related to the present paper are Swanson (1999), Zhou (2004), and Chaney and Ossa (2013). Swanson (1999) develops a model in which a larger market size leads to productivity gains, because workers specialize in a narrower subset of activities. Zhou (2004) develops a very different model which makes a similar point. Chaney and Ossa (2013) extend the new trade model of Krugman (1979) to allow for multiple production stages. However, Swanson (1999) does not explicitly consider the implications of international trade; the structure of the model means that this is not a straightforward analysis. In addition, unlike Zhou (2004) and Chaney and Ossa (2013), our model is based on perfect competition, so presents an alternative approach to the division of labour. In this sense the paper is related to Haveman and Hummels (2004), who provide an alternative explanation to the standard explanation of the gravity model of trade, and Davis (1995, 1997), who provides an alternative explanation for intra-industry trade (Davis, 1995) and trade between similar countries (Davis, 1997).

Also closely related to the present paper are Ethier $(1979,1982)$. The nature of the division of labour in this paper is similar to that in Ethier $(1979,1982)$. The main difference is that here, we explicitly model the division of labour as in Ethier (1982), but the production of intermediate inputs is perfectly competitive, whereas Ethier 
(1982) assumes monopolistic competition in the production of intermediate goods. Indeed, where Ethier (1982) has two sources of scale economies (internal to the firm, and due to the division of labour) and one source of comparative advantage (factor endowment differences across countries), in the present paper, there is one source of comparative advantage (between final goods), and one source of scale economies (the division of labour). In addition, whilst in Ethier (1982) there is, by assumption, no trade in final goods, here we allow for trade in both intermediate and final goods.

The model developed in Ethier (1982) was later used in a dynamic setting in the literature on endogenous growth (see especially Romer (1987) and Grossman and Helpman (1991)). In addition to providing the foundations for technological progress in the neoclassical growth model, Grossman and Helpman (1991) also endogenise the development of new varieties of intermediate inputs, which is the outcome of firms' decisions to engage in research and development. Grossman and Helpman's (1991) theoretical analysis of international technology diffusion has been examined empirically by Keller (2002a, 2002b; see also Keller's (2004) survey), who finds evidence of technological diffusion through trade in intermediate inputs, but also that technological spillovers are mainly local rather than global in nature. The insights from this literature are clearly important, but for simplicity we abstract from these issues in this paper.

The next section develops the model and outlines the autarkic equilibrium. Section 3 considers the implications of international trade, and the pattern of trade. Section 4 compares the results of the model, with a version of the model based on monopolistic competition. Section 5 provides some concluding comments.

\section{The model}

In this section we outline the features of a simple model of international trade in which countries may export both intermediate and final goods. There are two interesting results of the model. First, it shows the relationship between the division of labour and comparative advantage. Second, it predicts a negative relationship between the size of the economy and the consumption goods share of exports as documented in Figure 1.

There are two countries, $j=H, F$ for Home and Foreign. Labour is the only factor of production. The two countries have labour endowments $L_{j}$. All markets are perfectly 
competitive. There are two final consumption goods, 1 and 2. Consumer utility is identical across countries and takes a Cobb-Douglas form:

$$
U=C_{1}^{\theta} C_{2}^{1-\theta} \quad 0<\theta<1
$$

Where $C$ denotes consumption of a good. Final goods are produced with intermediate inputs. Each country has the ability to produce a number of intermediate inputs ${ }^{3}$ :

$$
n_{j}=r L_{j}
$$

where $r<1$ is a constant across countries (we ignore the integer constraint on $n_{j}$ ), each intermediate input is assumed to be different from all other intermediate inputs, and $n_{j}$ is small relative to the number of possible intermediate inputs. That is, the number of intermediate inputs a country can produce depends on the size of the labour force. There are at least two possible reasons for this. First, different groups of workers may have skills for producing different intermediate inputs, so the larger the labour force, the greater the variety of skills and hence intermediate goods available ${ }^{4}$. Second, there may be unmodelled intermediate-specific inputs (for instance, natural resources), so that, again, a larger country with a greater variety of natural resources would be able to produce more types of intermediate inputs. This idea relates to the literature which shows that larger countries are more diverse (Alesina and Spolaore (2003)). The parameter $r$ is a scaling factor which drops out of most expressions later on. It may be thought of as the intrinsic degree of specialisation in the economy; a larger value of $r$ implies a larger number of intermediate inputs for a given size of the labour force, so that the economy is more specialised.

As a result of equation (2), the number of intermediate goods produced by each country (hence the extent of the division of labour) is proportional to the size of the market, as in Adam Smith's example. The assumption that larger countries produce a larger variety of goods has empirical support from Hummels and Klenow (2005) and Hanson (2012). Let the production technology of intermediate inputs be identical across countries:

$$
q_{i j}=l_{i j}
$$

Production of intermediate inputs occurs under constant returns to scale. Each intermediate input is produced by a large number of perfectly competitive firms. As

\footnotetext{
${ }^{3}$ From a technical perspective, this assumption is needed to pin down the number of intermediate goods produced in an economy. Without this assumption, under perfect competition with constant returns to scale in the production of intermediate goods and increasing returns in the number of varieties, the optimal number of varieties is infinite.

${ }^{4}$ Swanson (1999) endogenises the specialisation of workers into different activities. This extension of the model is left to future work.
} 
a result of equation (3) and perfect competition, the price of each intermediate good is equal to the wage rate in each country. Since there are no trade costs, there are no home market effects of the Krugman (1980) type. Hence, assume that wage rates are equalised across countries, so that all intermediate goods have the same price ${ }^{5}$.

All intermediate inputs are used in fixed proportions in the production of final goods, and assembly of final goods is assumed to be $\operatorname{costless}^{6}$. Hence let the production functions of the final goods in the two countries be:

$$
\begin{array}{ll}
Q_{1 H}=\gamma\left(n_{H}+n_{F}\right)^{\beta+1} x_{1 H} & Q_{2 H}=\left(n_{H}+n_{F}\right)^{\beta+1} x_{2 H} \\
Q_{1 F}=\left(n_{H}+n_{F}\right)^{\beta+1} x_{1 F} & Q_{2 F}=\gamma\left(n_{H}+n_{F}\right)^{\beta+1} x_{2 F}
\end{array}
$$

Output of each final good depends on the number of Home and Foreign produced inputs, $n_{H}$ and $n_{F}$, and the quantity of each intermediate input, $x$. Assume perfect knowledge transfer across countries, so that foreign and domestic inputs enter symmetrically into production ${ }^{7} \cdot \gamma>1$ indicates that Home has a comparative technological advantage in final good 1, while Foreign has a comparative technological advantage in final good 2. $\beta>0$ measures the payoff from the division of labour ${ }^{8}$. The larger the number of intermediate inputs $n$, the greater the division of labour, and the larger the output of the final good, analogously to Adam Smith's pin factory example. Note that the production function of final goods exhibits constant returns to scale with respect to the quantity of each input, and increasing returns with respect to the number of different inputs. The constant returns to scale feature makes the production function compatible with perfect competition: a larger firm does not have a cost advantage relative to a smaller firm.

\footnotetext{
${ }^{5}$ This is a weaker (and more common) assumption than it may seem at first sight. Introducing an additional homogeneous final good as is commonly done in the literature (Helpman and Krugman (1985), Fujita et al (1999)) does not obviate the need for this assumption. As Davis (1998) notes, in the absence of trade costs, the division of resources between the homogeneous and differentiated goods between countries is indeterminate. Even when there are trade costs (as in Helpman and Krugman (1985)), the assumption that both countries produce the homogeneous good is needed to ensure wage equality across countries.

${ }^{6}$ Alternatively, some of the intermediate inputs may be interpreted as assembly services, so that assembly is not costless. This interpretation would leave the results unchanged.

${ }^{7}$ Hence abstracting from the localised nature of knowledge spillovers; see Keller (2002a).

${ }^{8}$ What if $\beta<0$ ? In this case, there are decreasing returns to the number of different inputs. Hence, final goods firms will use the largest quantity of the smallest number of different inputs. In doing this, they are constrained by equation (2), so that, in autarky, final good 1 will use all the output of $\theta n_{j}$ inputs, while final good 2 will use all the output of $(1-\theta) n_{j}$ inputs. It is possible to trace out the implications for the pattern of trade, but this is beyond the scope of the present paper.
} 
Consider the case where the two countries do not trade with each other. Here we analyse the Home country; the solution for the Foreign country is analogous. In this case, Foreign-produced intermediates are not available for use in the production of Home-produced final goods, and all Home-produced intermediates are used at Home. Because of the Cobb-Douglas preferences, each country will produce both final goods in autarky, and because of constant returns to scale with respect to the quantity of each input in final good production, the production possibilities frontier (PPF) is a straight line; there are constant opportunity costs. As a result, we can allocate the output of each intermediate good to the two final goods based on the parameter of the utility function $\theta$ (see Appendix B for a derivation):

$$
x_{1 H}=\theta q_{i H} \quad x_{2 H}=(1-\theta) q_{i H}
$$

Where $q_{i H}$ is the output of each intermediate good in Home. Hence, the production functions in Home are (making use of equation (2)):

$$
\begin{aligned}
& Q_{1 H}=\gamma n_{H}^{\beta+1} \theta q_{i H}=\gamma\left(r L_{H}\right)^{\beta+1} \theta q_{i H} \\
& Q_{2 H}=n_{H}^{\beta+1}(1-\theta) q_{i H}=\left(r L_{H}\right)^{\beta+1}(1-\theta) q_{i H}
\end{aligned}
$$

Since all intermediate inputs are produced using the same technology, and since all intermediate goods are used in fixed proportions in the production of final goods, the labour used in each intermediate input is also the same. Hence from equations (2) and (3) we have:

$$
q_{i H}=l_{i H}=\frac{L_{H}}{n_{H}}=\frac{1}{r}
$$

The size of the labour force influences only the number of intermediate goods, not the output of each intermediate good. This result of the model is similar to Krugman (1980), in which changing labour endowments results in a different number of varieties produced, but not the scale of production of each variety.

Substituting equation (7) into the production functions (6a) and (6b) gives:

$$
Q_{1 H}=\left(r L_{H}\right)^{\beta} \gamma \theta L_{H} \quad Q_{2 H}=\left(r L_{H}\right)^{\beta}(1-\theta) L_{H}
$$

Since there is no international trade, Home consumers can only consume Homeproduced output. Therefore, the Home consumer's per capita utility under autarky is:

$$
U_{H}^{A}=\left(r L_{H}\right)^{\beta}(\gamma \theta)^{\theta}(1-\theta)^{1-\theta}
$$

Per capita utility is increasing in the size of the Home labour force $L_{H}$ (a larger economy benefits from greater division of labour), the parameter $r$ indicating the intrinsic degree of specialisation in the economy, the gain from the division of labour 
$\beta$, and the technology parameter $\gamma$. In addition, utility has a U-shaped relationship with the share of final good 1 in expenditure, $\theta$.

\section{$3 \quad$ International trade}

When international trade is allowed, assume there are no trade costs, so that both intermediate inputs and final goods can be freely traded across countries. Proposition 1 shows that both countries are always specialized in free trade:

Proposition 1: In free trade, Home is specialized in final good 1 and Foreign is specialized in final good 2 .

At first sight, Proposition 1 appears to originate from equations (4a) and (4b) where Home has comparative advantage in final good 1, and Foreign in final good 2, as in the standard Ricardian model. However, in fact Proposition 1 arises because of absolute advantage, not comparative advantage. Because production of final goods from intermediate goods does not require any additional resources beyond the intermediate goods already produced, if a country is more productive at producing both final goods, then the efficient allocation of resources (the integrated equilibrium; see Helpman and Krugman (1985)) implies that both final goods will be produced in that country ${ }^{9}$. Effectively, there is no opportunity cost of producing one final good instead of the other, but because we assumed in equations (4a) and (4b) that each country has a technological advantage in one final good (and constant returns to scale with respect to the quantity of each input), each country is completely specialized in producing that good.

Making use of the results in the previous section and solving for the production functions (4a) and (4b) gives:

$$
\begin{aligned}
& Q_{1 H}=\gamma \theta\left(r L_{H}+r L_{F}\right)^{\beta}\left(L_{H}+L_{F}\right) \\
& Q_{2 F}=\gamma(1-\theta)\left(r L_{H}+r L_{F}\right)^{\beta}\left(L_{H}+L_{F}\right)
\end{aligned}
$$

Production of each final good uses intermediate goods produced in both countries, and consumers wish to consume both final goods. Hence international trade occurs in both intermediate and final goods ${ }^{10}$.

\footnotetext{
${ }^{9}$ A similar argument has been made in Davis (1995), who develops a model where one country has an (absolute) technological advantage in a good. To replicate the integrated equilibrium, it must be the case that the country with the technological advantage, produces the world output of that good.

${ }^{10}$ If trade in intermediate goods is defined to be intra-industry trade, while trade in final goods is inter-industry, then the model predicts both inter- and intra-industry trade. More details are provided
} 
Since preferences are homothetic and identical across countries, each country will consume a fraction of the total output of each final good which is proportional to its relative size $L_{j} /\left(L_{H}+L_{F}\right)$. Hence, the Home consumer's per capita utility under free trade is:

$$
U_{H}^{F T}=\gamma\left(r L_{H}+r L_{F}\right)^{\beta} \theta^{\theta}(1-\theta)^{1-\theta}
$$

Define the gains from trade as the ratio between free trade (11) and autarkic utility (9). The gains from trade for the Home country are:

$$
G_{H}=\frac{U_{H}^{F T}}{U_{H}^{A}}=\left(\frac{L_{H}+L_{F}}{L_{H}}\right)^{\beta} \gamma^{1-\theta}>1
$$

Hence there are gains from trade, which arise from two sources. First, international trade leads to more intermediate goods being available, which leads to greater division of labour. Second, international trade allows the two countries to specialize in their comparative advantage final goods. The following comparative statics results can be shown:

$$
\frac{d G_{H}}{d L_{H}}<0 \quad \frac{d G_{H}}{d L_{F}}>0 \quad \frac{d G_{H}}{d \beta}>0 \quad \frac{d G_{H}}{d \gamma}>0 \quad \frac{d G_{H}}{d \theta}<0
$$

As might be expected, the gains from trade increase the smaller is the country, or the larger is the trading partner. In fact, from equation (11), it can be seen that utility under free trade depends on the size of the world economy rather than the size of each country, and is identical for both countries. The larger the gains from the division of labour $\beta$ or the larger the comparative technological advantage in the final good $\gamma$, the larger the gains from trade. Similarly, the larger the expenditure share of final good $1, \theta$, the smaller the gains from trade for Home, since Home has comparative advantage in good 1 .

It is possible to decompose the total gains from trade into the component derived from comparative advantage in final goods production and the component derived from the division of labour. To obtain the Home country's gains from trade based on comparative advantage alone, set $\beta=0$ in the gains from trade equation (12) to obtain:

$$
G_{C A}=\gamma^{1-\theta}
$$

Similarly, set $\gamma=1$ in equation (12) to obtain the Home country's gains from trade based on the division of labour alone:

in Appendix C, where it is shown that the model's prediction of the share of intra-industry trade is the same as that of the imperfect competition model of Helpman and Krugman (1985). 


$$
G_{D L}=\left(\frac{L_{H}+L_{F}}{L_{H}}\right)^{\beta}
$$

Total gains from trade are simply the product of the two components:

$$
G_{H}=G_{C A} \times G_{D L}
$$

Note from equation (14) that the gain from comparative advantage is independent of country sizes, whereas from equation (15) the gain from the division of labour increases the smaller is the country relative to its trading partner. Hence the primary source of the gains from trade for small countries is the division of labour, while for large countries it is comparative advantage. We have:

Proposition 2: The smaller is a country relative to its trading partner, the greater the importance of the division of labour relative to comparative advantage as a source of the gains from trade.

As noted in Section 2 above, the two countries are symmetric in every way except one: their size. Similarly, the two final goods and all intermediate goods are also symmetric in every way, and international trade and the assembly of final goods from intermediate goods are costless. As a result, the total value of intermediate goods output is equal to the total value of final goods output, and the two final goods are produced in proportion to the parameters of the Cobb-Douglas utility function and have equal prices. However, with identical homothetic preferences, the larger country will consume a larger fraction of each final good, in direct proportion to the country's size. As a result, the share of the final good in a country's exports will be negatively related to the country's size, while the share of intermediate goods will be positively related to the country's size.

To make this more concrete, the value of Home's exports of the final good is:

$$
\frac{L_{F}}{L_{H}+L_{F}} P_{1} Q_{1 H}=\frac{L_{F}}{L_{H}+L_{F}} P_{1}\left(\frac{\gamma \theta}{r}\right)\left(r L_{H}+r L_{F}\right)^{\beta+1}=L_{F} P_{1} \gamma \theta\left(r L_{H}+r L_{F}\right)^{\beta}
$$

Where $P_{1}$ is the price of good 1. Recall from equation (5) that a fraction $1-\theta$ of each Home-produced intermediate good is used in the production of final good 2, which is produced in Foreign. The value of Home's exports of intermediate goods is:

$$
(1-\theta) p_{H} q_{i H} n_{H}=(1-\theta) p_{H} L_{H}
$$

Where $p_{H}$ is the price of each intermediate good. The price of each intermediate good does not depend on the country's size. Since we have assumed in Section 2 above that wage rates are equal across countries, the prices of intermediate goods are also the same across countries and can be normalised to 1 . However, the price of the final 
good does depend on the size of the world economy, since a larger world economy implies more intermediate goods and hence lower production cost through greater division of labour. The relative price of the final good can be obtained from the assumptions that international trade and the assembly of the final goods are costless and profits are zero, so the value of final good output is equal to the value of the intermediate inputs used in its production. That is, from equation (10a):

$$
P_{1} Q_{1 H}=P_{1} \gamma \theta\left(r L_{H}+r L_{F}\right)^{\beta}\left(L_{H}+L_{F}\right)
$$

While the value of the intermediate inputs used in its production is, substituting from equation (5):

$$
p_{H}\left(n_{H}+n_{F}\right) x_{1 H}=p_{H}\left(r L_{H}+r L_{F}\right) \theta q_{H}=p_{H}\left(L_{H}+L_{F}\right) \theta
$$

If profits are zero, equations (19) and (20) are equal to one another, and setting $p_{H}=$ 1 gives the price of the Home-produced final good as a function of the endowments:

$$
P_{1}=\left[\gamma\left(r L_{H}+r L_{F}\right)^{\beta}\right]^{-1}
$$

Substituting this into the value of Home's exports of the final good (17) and simplifying gives:

$$
\theta L_{F}
$$

Combining this with the value of Home's exports of intermediate goods (18), Home's exports of the final good as a share of Home's total exports is:

$$
\theta L_{F}\left[\theta L_{F}+(1-\theta) L_{H}\right]^{-1}
$$

Differentiating this expression with respect to $L_{H}$ gives the relationship between the share of final goods exports and country size:

$$
\frac{d}{d L_{H}}=-L_{F} \theta(1-\theta)\left[\theta L_{F}+(1-\theta) L_{H}\right]^{-2}<0
$$

This gives:

Proposition 3: There is a negative relationship between country size and the share of final goods in its exports, and a positive relationship between country size and the share of intermediate goods in its exports.

Proposition 3 is of course the same as the empirical relationship obtained in Figure 1. In fact, since labour is the only factor of production and profits are zero in equilibrium, a country's GDP as measured by the income approach is simply the wage income $w_{j} L_{j}$. In Appendix $\mathrm{A}$, we show empirically that the negative relationship between country size and the share of final goods in its exports holds whether we use GDP or total labour compensation as the measure of size. 


\section{Comparison with the model based on monopolistic competition}

Appendix D outlines a version of the model based on monopolistic competition. This model is similar to that presented in Krugman (1980) and Ethier (1982). There are two points of departure between the model presented in Sections 2 and 3 above, and the model in Appendix D. First, in Appendix D, we assume monopolistic competition and increasing returns to scale in the production of intermediate goods. This compares with the model in the text, which assumes constant returns to scale in intermediate goods production. Second, in Appendix D, we assume a Constant Elasticity of Substitution (CES) aggregator for the production function of the final goods. This compares with the production functions (4a) and (4b) which directly model the role of the division of labour. The two points of departure enable the model in Appendix D to yield an endogenously-determined number of intermediate goods, and also to make each firm synonymous with a single variety of intermediate good.

It turns out that both models yield the same outcomes ${ }^{11}$. This can be seen most clearly in two cases. First, in both models, the gains from trade arise both from comparative advantage, and from the increased number of varieties of intermediate inputs. Second, the expression for the share of consumption goods in Home's total exports is exactly the same between the two models. What this suggests, as argued in the Introduction, is that it is possible to derive a model of intermediate goods trade based on perfect competition, which yields the same results as the moreconventional model based on monopolistic competition.

To be clear, we do not set out to claim that the perfectly competitive model is somehow superior to the model based on monopolistic competition. Instead, what we hope to show is that, in this instance, the results obtained using both approaches are the same. There are of course instances in which the monopolistic competition model is superior, such as in the literature pioneered by Melitz (2003) on firm heterogeneity ${ }^{12}$. Nevertheless, as the recent literature on the gravity model shows

\footnotetext{
${ }^{11}$ This is true as long as the standard CES formulation is used, as is the case in Appendix D. If for instance we adopt the specification used in Krugman (1980) for the production functions, viz. $Q_{1 H}=$ $\gamma\left[\sum x_{1 H}^{\rho}+\sum x_{i F}^{\rho}\right]$ and $Q_{2 H}=\sum x_{2 H}^{\rho}+\sum x_{2 F}^{\rho}$, then it can be shown that the gains from trade arise only because of comparative advantage (that is, there are no gains from the increased variety of intermediate inputs), while the result for the consumption goods share of trade remains unchanged.

${ }^{12}$ Although even here Bond (1986) shows that is it possible to introduce firm heterogeneity in a Heckscher-Ohlin model.
} 
(Eaton and Kortum (2002)), there remains a place for models based on comparative advantage. Recent developments in empirical methods which are agnostic to the market structure (for instance, De Loecker and Warzynski (2012)) may represent an important step in the literature.

\section{$5 \quad$ Conclusions}

In this paper, we document the presence of a negative relationship between the size of a country, and the share of consumption goods in its total exports. We develop a simple model of international trade which is able to explain this negative relationship. The model is based on the division of labour and comparative advantage, going beyond the usual assumption of external scale economies to clarify the implications of the division of labour. Unlike most of the prior literature, the model is perfectly competitive throughout. The extent of the division of labour is determined by the size of the market, whereas the gains from international trade arise from the division of the production process into increasing numbers of stages and from comparative advantage in final goods. It is shown that large countries gain relatively more from comparative advantage than from the division of labour, whereas the opposite is true for small countries. Countries exchange intermediate inputs which are used in the production of final goods, which are then traded with each other. In addition, the model predicts, consistently with the empirical evidence, that larger countries will have a smaller share of consumption goods in their exports, and a larger share of intermediate goods. It is shown in Appendix D that the perfectly competitive model developed in the paper yields the same outcomes as a model based on monopolistic competition.

The model developed in this paper relies quite heavily on several strong assumptions, especially those regarding the production of intermediate inputs and final goods. As discussed in the paper, these assumptions help sidestep some analytically difficult issues. Future work will address these issues directly, as well as developing a more general approach that would be amenable to the analysis of related issues such as trade costs. Nevertheless, the present paper helps to shed some light not only on the relationship between country size and intermediate goods trade, but also on the role of the division of labour, and the relationship between the division of labour and comparative advantage, in international trade. 


\section{References}

Alesina, A., Spolaore, E., 2003. The size of nations. Cambridge, MA, MIT Press.

Bond, E.W., 1986. Entrepreneurial ability, income distribution, and international trade. Journal of International Economics 20(3-4), 343-356.

Chaney, T., Ossa, R., 2013. Market size, division of labour, and firm productivity. Journal of International Economics 90(1), 177-180.

Choi, J.-Y., Yu, E.S.H., 2003. External economies in the international trade theory: A survey, in Choi, E.K., Harrigan, J. (eds.) Handbook of International Trade. Blackwell Publishing, 186-212.

Davis, D.R., 1995. Intra-industry trade: A Heckscher-Ohlin-Ricardo approach. Journal of International Economics 39(3-4), 201-226.

Davis, D.R., 1997. Critical evidence on comparative advantage? North-north trade in a multilateral world. Journal of Political Economy 105(5), 1051-1060.

Davis, D.R., 1998. The home market, trade, and industrial structure. American Economic Review 88(5), 1264-1276.

De Loecker, J., Warzynski, F., 2012. Markups and firm-level export status. American Economic Review 102(6), 2437-2471.

Eaton, J., Kortum, S., 2002. Technology, geography and trade. Econometrica 70(5), 1741-1779.

Ethier, W.J., 1979. Internationally decreasing costs and world trade. Journal of International Economics 9(1), 1-24.

Ethier, W.J., 1982. National and international returns to scale in the modern theory of international trade. American Economic Review 72(3), 389-405.

Ethier, W.J., Ruffin, R.J., 2009. External economies of scale and comparative advantage, in Kamihigashi, T., Zhao, L. (eds) International Trade and Economic Dynamics: Essays in Memory of Koji Shimomura, Springer, pp. 37-47. 
Feenstra, R.C., Inklaar, R., Timmer, M.P., 2015. The next generation of the Penn World Table. American Economic Review 105(10), 3150-3182.

Fujita, M., Krugman, P.R., Venables, A.J., 1999. The spatial economy. Cambridge, MA, MIT Press.

Grossman, G.M., Helpman, E., 1991. Innovation and growth in the global economy. Cambridge, MA, MIT Press.

Grossman, G.M., Rossi-Hansberg, E., 2010. External economies and international trade redux. Quarterly Journal of Economics 125(2), 829-858.

Hanson, G.H., 2012. The rise of middle kingdoms: Emerging economies in global trade. Journal of Economic Perspectives 26(2), 41-64.

Haveman, J., Hummels, D., 2004. Alternative hypotheses and the volume of trade: The gravity equation and the extent of specialization. Canadian Journal of Economics 37(1), 199-218.

Helpman, E., 1987. Imperfect competition and international trade: Evidence from fourteen industrial countries. Journal of the Japanese and International Economies $1(1), 62-81$.

Helpman, E., Krugman, P.R., 1985. Market structure and foreign trade. Cambridge, MA, MIT Press.

Hsieh, C.-T., Ossa, R., 2016. A global view of productivity growth in China. Journal of International Economics 102, 209-224.

Hummels, D., Klenow, P.J., 2005. The variety and quality of a nation's exports. American Economic Review 95(3), 704-723.

Hummels, D., Levinsohn, J., 1995. Monopolistic competition and international trade: Reconsidering the evidence. Quarterly Journal of Economics 110(3), 799-836.

Jones, R.W., 2000. Globalization and the theory of input trade. Cambridge, MA, MIT Press. 
Keller, W., 2002a. Geographic localization of international technology. American Economic Review 92(1), 120-142.

Keller, W., 2002b. Trade and the transmission of technology. Journal of Economic Growth 7(1), 5-24.

Keller, W., 2004. International technology diffusion. Journal of Economic Literature $42(3), 752-782$.

Krugman, P.R., 1979. Increasing returns, monopolistic competition, and international trade. Journal of International Economics 9(4), 469-479.

Krugman, P.R., 1980. Scale economies, product differentiation, and the pattern of trade. American Economic Review 70(5), 950-959.

Melitz, M.J., 2003. The impact of trade on intra-industry reallocations and aggregate industry productivity. Econometrica 71(6), 1695-1725.

Miroudot, S., Lanz, R., Ragoussis, A., 2009. Trade in intermediate goods and services. OECD Trade Policy Papers No. 93.

Ricardo, D., 1817. On the principles of political economy and taxation. John Murray, London.

Romer, P.M., 1987. Growth based on increasing returns due to specialization. American Economic Review 77(2), 56-62.

Smith, A., 1776. An inquiry into the nature and causes of the Wealth of Nations. W. Strahan and T. Cadell, London.

Sturgeon, T.J., Memedovic, O., 2010. Mapping global value chains: Intermediate goods trade and structural change in the world economy. UNIDO Development Policy and Strategic Research Branch Working Paper 05/2010.

Swanson, C.E., 1999. The division of labour and the extent of the market. Economics Letters 62(1), 135-138. 
The Economist, 2015. Made in China? [online], available at http://www.economist.com/news/leaders/21646204-asias-dominance-manufacturingwill-endure-will-make-development-harder-others-made [Accessed 16 August 2016].

United Nations, 2002. Classification by broad economic categories. Statistical Papers Series M No. 53, Rev. 4.

Zhou, H., 2004. The division of labour and the extent of the market. Economic Theory 24(1), 195-209. 


\section{Appendix A: Econometric analysis}

In this Appendix, we develop an econometric model to provide further evidence on the negative relationship between country size and the share of consumption goods in international trade. The data used for the empirical analysis has been obtained from the UN Comtrade database, for all available countries between 1995 and 2014. We make use of the Broad Economic Categories (BEC) classification which divides all commodities into capital goods, intermediate goods, consumption goods, and "unclassified" (see United Nations (2002) for details of the classification). For our analysis, we drop the "unclassified" category, and exclude agricultural and mining products from the sample, before calculating the share of each type of good in total exports $^{13}$. It may be argued that agricultural and mining products make less use of intermediate inputs than manufactured products, so their inclusion may influence the results. Our sample is an unbalanced panel of 170 countries, and, in the sample, the share of consumption goods in total exports is $23.9 \%$, while the share of intermediate goods is $56.6 \%$, and the share of capital goods is $19.4 \%$. We use two measures of country size: real GDP at constant 2011 national prices, and total labour compensation in the economy (calculated as the share of labour compensation in GDP, multiplied by real GDP). In the one-factor model in the text, these two measures are identical, since all national income is labour income; empirically, they may differ depending on factors such as capital endowments, although the correlation between the two measures is 0.99. Both measures are obtained from the Penn World Tables 9.0 (Feenstra et al, 2015).

We estimate the following equation:

$$
\left(\frac{X_{c i t}}{X_{i t}}\right)=\alpha_{0 i}+\alpha_{1 t}+\alpha_{2} \ln \operatorname{Size}_{i t}+\epsilon_{i t}
$$

Where $X_{c i t}$ is exports of consumption goods, and $X_{i t}$ is total exports, of country $i$ in year $t$. We include both country and year fixed effects $\alpha_{0 i}$ and $\alpha_{1 t}$, to control for unobserved time-invariant heterogeneity across countries (for example, differences in industrial structure across countries), and country-invariant heterogeneity across time (for instance, shocks which are common across countries). By controlling for both country and year fixed effects, the coefficient on $\ln$ Size $_{i t}$ is identified through across-time variation within country. That is, $\alpha_{2}$ shows how the consumption share of exports changes as a country's size changes. The specification in (A1) helps to

\footnotetext{
${ }^{13}$ Including the "unclassified" category and agricultural and mining products leads to qualitatively similar results to those reported below.
} 
address one potential concern from Figure 1: because Figure 1 uses cross-sectional data, the relationship obtained may be driven by some unobserved cross-sectional differences across countries.

Changes in the structure of the economy (for instance, the de-industrialisation of many developed economies) may also influence the consumption share of exports. To control for this, we also include a set of country-specific time trends, giving the following estimated equation:

$$
\left(\frac{X_{c i t}}{X_{i t}}\right)=\alpha_{0 i}+\left(\alpha_{0 i} \times \text { time }\right)+\alpha_{1 t}+\alpha_{2} \ln \text { Size } e_{i t}+\epsilon_{i t}
$$

The results from regressing equations (A1) and (A2), making use of both size measures, are reported in Table A1. Controlling for country fixed effects (columns (1) and (4)), both GDP and labour compensation are negatively and significantly related to the consumption goods share of exports. A one percent increase in GDP reduces the consumption goods share of exports by about 0.06 percent, with labour compensation having a slightly smaller effect. Including year fixed effects (columns (2) and (5)) reduces the significance in both cases, while adding a country-specific time trend (columns (3) and (6)) restores the statistical significance of GDP ${ }^{14}$.

We perform three sensitivity checks on the results of Table A1. First, note that the sample is an unbalanced panel; with 170 countries and 20 years, a balanced panel would have 3,400 observations, but Table 1 only has 2,583 observations (fewer countries and observations are available when using labour compensation). Therefore, we may be concerned with non-random sample attrition. To address this concern, we perform the analysis with a panel which includes only countries with at least 12 observations. This reduces the number of countries, to 144, and the number of observations, to 2,429 , but increases the average number of observations per country, from 15.2 to 16.9 .

A second concern is that the regression analysis in Table A1 gives equal importance to all countries in the sample. We consider two approaches to addressing this concern. First, we perform a regression in which the observations are weighted by the natural $\log$ of population, so that larger countries are given greater weight in the regression ${ }^{15}$. Second we drop all countries which are in the bottom decile in terms of population and GDP; this corresponds to a population threshold of approximately

\footnotetext{
${ }^{14}$ It is possible that both size measures are endogenous in equations (A1) and (A2). However, whilst total exports may influence size, it is not immediately obvious how the structure of exports would do so.

${ }^{15}$ Alternative weights, such as the natural $\log$ of GDP, yield very similar results.
} 
600,000 people and a GDP threshold of approximately $\$ 8.1$ billion. This results in the exclusion of 43 countries in total; these are mainly small island states such as Seychelles and Samoa, but also includes a few wealthy but small countries such as Brunei and Luxembourg.

The results of these sensitivity analyses are reported in Table A2, where the same specifications as Table A1 are reported: country size is measured either with real GDP or labour compensation, with country fixed effects only, with country and year fixed effects, and with country and year fixed effects and country-specific time trends. Panel A reports the results of the more balanced sample; Panel B reports the results of the weighted regression; and Panel $\mathrm{C}$ reports the results of dropping small countries. In all cases we get very similar results to those reported in Table A1. In particular, both measures of size are always negatively (albeit not always significantly) related to the consumption goods share of exports. This suggests that the results presented in Table A1 are quite robust, and are not driven by sample selection.

Table A1: The relationship between the consumption share of exports and country size. Dependent variable $=$ consumption goods share of exports.

\begin{tabular}{|c|c|c|c|c|c|c|}
\hline & (1) & $(2)$ & $(3)$ & (4) & (5) & (6) \\
\hline $\ln ($ real GDP $)$ & $\begin{array}{l}-0.056 \\
(0.021)^{* *}\end{array}$ & $\begin{array}{l}-0.048 \\
(0.048)\end{array}$ & $\begin{array}{l}-0.106 \\
(0.038)^{* *}\end{array}$ & & & \\
\hline $\ln ($ Labour comp $)$ & & & & $\begin{array}{l}-0.049 \\
(0.021)^{*}\end{array}$ & $\begin{array}{l}-0.025 \\
(0.035) \\
\end{array}$ & $\begin{array}{c}-0.039 \\
(0.025) \\
\end{array}$ \\
\hline$R^{2}$ & 0.03 & 0.03 & 0.46 & 0.02 & 0.04 & 0.49 \\
\hline$N \times T$ & 2,583 & 2,583 & 2,583 & 2,093 & 2,093 & 2,093 \\
\hline$N$ & 170 & 170 & 170 & 130 & 130 & 130 \\
\hline Country FE & Yes & Yes & Yes & Yes & Yes & Yes \\
\hline Year FE & & Yes & Yes & & Yes & Yes \\
\hline Country time trend & & & Yes & & & Yes \\
\hline
\end{tabular}


Table A2: Sensitivity analysis. Dependent variable = consumption goods share of exports.

\begin{tabular}{|c|c|c|c|c|c|c|}
\hline \multicolumn{7}{|c|}{ Panel A: More balanced panel } \\
\hline & (1) & $(2)$ & $(3)$ & $(4)$ & $(5)$ & $(6)$ \\
\hline $\ln ($ real GDP $)$ & $\begin{array}{l}-0.064 \\
(0.022)^{* *}\end{array}$ & $\begin{array}{l}-0.048 \\
(0.050)\end{array}$ & $\begin{array}{l}-0.118 \\
(0.035)^{* *}\end{array}$ & & & \\
\hline $\ln ($ Labour comp $)$ & & & & $\begin{array}{l}-0.057 \\
(0.021)^{* *}\end{array}$ & $\begin{array}{l}-0.033 \\
(0.037) \\
\end{array}$ & $\begin{array}{l}-0.048 \\
(0.025)+\end{array}$ \\
\hline$R^{2}$ & 0.04 & 0.04 & 0.47 & 0.03 & 0.04 & 0.51 \\
\hline$N \times T$ & 2,429 & 2,429 & 2,429 & 2,026 & 2,026 & 2,026 \\
\hline$N$ & 144 & 144 & 144 & 119 & 119 & 119 \\
\hline Country FE & Yes & Yes & Yes & Yes & Yes & Yes \\
\hline Year FE & & Yes & Yes & & Yes & Yes \\
\hline Country time trend & & & Yes & & & Yes \\
\hline
\end{tabular}

Panel B: Weighted Regression

\begin{tabular}{|c|c|c|c|c|c|c|}
\hline & (7) & (8) & (9) & (10) & (11) & $(12)$ \\
\hline $\ln ($ real GDP $)$ & $\begin{array}{l}-0.057 \\
(0.021)^{* *}\end{array}$ & $\begin{array}{l}-0.044 \\
(0.046)\end{array}$ & $\begin{array}{l}-0.108 \\
(0.035) * *\end{array}$ & & & \\
\hline $\ln ($ Labour comp $)$ & & & & $\begin{array}{l}-0.050 \\
(0.021) *\end{array}$ & $\begin{array}{l}-0.019 \\
(0.032) \\
\end{array}$ & $\begin{array}{l}-0.038 \\
(0.025) \\
\end{array}$ \\
\hline$R^{2}$ & 0.03 & 0.04 & 0.46 & 0.02 & 0.04 & 0.48 \\
\hline$N \times T$ & 2,583 & 2,583 & 2,583 & 2,093 & 2,093 & 2,093 \\
\hline$N$ & 170 & 170 & 170 & 130 & 130 & 130 \\
\hline Country FE & Yes & Yes & Yes & Yes & Yes & Yes \\
\hline Year FE & & Yes & Yes & & Yes & Yes \\
\hline Country time trend & & & Yes & & & Yes \\
\hline
\end{tabular}

Panel C: Excluding Small Countries

\begin{tabular}{|c|c|c|c|c|c|c|}
\hline & (13) & (14) & $(15)$ & $(16)$ & $(17)$ & (18) \\
\hline $\ln ($ real GDP $)$ & $\begin{array}{l}-0.063 \\
(0.023)^{* *}\end{array}$ & $\begin{array}{l}-0.029 \\
(0.049)\end{array}$ & $\begin{array}{l}-0.125 \\
(0.034)^{* *}\end{array}$ & & & \\
\hline $\ln ($ Labour comp $)$ & & & & $\begin{array}{l}-0.061 \\
(0.021) * *\end{array}$ & $\begin{array}{l}-0.010 \\
(0.028)\end{array}$ & $\begin{array}{l}-0.043 \\
(0.025)+\end{array}$ \\
\hline$R^{2}$ & 0.05 & 0.06 & 0.46 & 0.04 & 0.07 & 0.47 \\
\hline$N \times T$ & 2,125 & 2,125 & 2,125 & 1,842 & 1,842 & 1,842 \\
\hline$N$ & 127 & 127 & 127 & 110 & 110 & 110 \\
\hline Country FE & Yes & Yes & Yes & Yes & Yes & Yes \\
\hline Year FE & & Yes & Yes & & Yes & Yes \\
\hline Country time trend & & & Yes & & & Yes \\
\hline
\end{tabular}

Notes: Figures in parentheses are standard errors clustered by country. + Significant at 10\%; * significant at $5 \%$; ${ }^{* *}$ significant at $1 \%$. Estimation is by OLS with fixed effects as defined in the table. All specifications include observations from 1995 to 2014. 


\section{Appendix B: The autarkic equilibrium}

To obtain the autarkic equilibrium for the Home country, set the slope of the PPF equal to the slope of the indifference curve. From the Cobb-Douglas utility function (1), the slope of the indifference curve in equilibrium is:

$$
\frac{P_{1 H}}{P_{2 H}}=\frac{\theta}{1-\theta} \frac{C_{2 H}}{C_{1 H}}
$$

To derive the PPF, first note that because of constant returns to scale in the production of intermediate goods, we have:

$$
\frac{x_{1 H}}{x_{1 H}+x_{2 H}}=\frac{L_{1 H}}{L_{1 H}+L_{2 H}}
$$

Where $L_{1 H}$ and $L_{2 H}$ are the total labour used in the Home country in producing the intermediate inputs used in goods 1 and 2. Rearranging (B2) and substituting into the production functions (4a), noting that in autarky, market clearing implies $x_{1 H}+$ $x_{2 H}=q_{i H}$ and $L_{1 H}+L_{2 H}=L_{H}$, we have:

$$
Q_{1 H}=\gamma n_{H}^{\beta+1}\left(\frac{q_{i H}}{L_{H}}\right) L_{1 H} \quad \text { and } \quad Q_{2 H}=n_{H}^{\beta+1}\left(\frac{q_{i H}}{L_{H}}\right) L_{2 H}
$$

Hence:

$$
L_{1 H}=\frac{L_{H} Q_{1 H}}{q_{i H} \gamma n_{H}^{\beta+1}} \quad \text { and } \quad L_{2 H}=\frac{L_{H} Q_{2 H}}{q_{i H} n_{H}^{\beta+1}}
$$

Hence the equation of the PPF is:

$$
L_{H}=L_{1 H}+L_{2 H}=\frac{L_{H} Q_{1 H}}{q_{i H} \gamma n_{H}^{\beta+1}}+\frac{L_{H} Q_{2 H}}{q_{i H} n_{H}^{\beta+1}}
$$

Rearranging in terms of $Q_{2 H}$ :

$$
Q_{2 H}=q_{i H} n_{H}^{\beta+1}-\frac{Q_{1 H}}{\gamma}
$$

The slope of the PPF, which is also the no-trade relative price of final good 1 , is:

$$
-\frac{d Q_{2 H}}{d Q_{1 H}}=\frac{P_{1 H}}{P_{2 H}}=\frac{1}{\gamma}
$$

Setting (B7) equal to the slope of the indifference curve (B1), making use of the fact that autarkic market clearing implies $C_{1 H} L_{H}=Q_{1 H}$ and $C_{2 H} L_{H}=Q_{2 H}$, and substituting from (B2) and (B3) gives the relationship between $x_{1 H}$ and $x_{2 H}$ :

$$
x_{1 H}=\frac{\theta}{1-\theta} x_{2 H}
$$

Making use of the market clearing condition $x_{1 H}+x_{2 H}=q_{i H}$ gives:

$$
x_{1 H}=\theta q_{i H} \quad x_{2 H}=(1-\theta) q_{i H}
$$

Which is equation (5) in the text, showing how the output of intermediate inputs is divided between the two final goods. 


\section{Appendix C: Intra-industry trade}

From Section 3, Home's exports and imports may be summarised as follows (assuming prices of intermediate inputs $p_{H}=p_{F}=1$ ):

Home exports of final good 1:

$\theta L_{F}$

Home imports of final good 2:

$$
(1-\theta) L_{H}
$$

Home exports of intermediate goods: $\quad(1-\theta) L_{H}$

Home imports of intermediate goods: $\theta L_{F}$

Suppose that the two final goods are defined as two separate industries, and intermediate goods as a third industry. Then, defining the Grubel-Lloyd index of intra-industry trade in each industry $k$ as:

$$
G L_{k}=1-\frac{\left|X_{k}-M_{k}\right|}{X_{k}+M_{k}}
$$

Where $X$ and $M$ are exports and imports. We have:

$$
\begin{gathered}
G L_{\text {intermediates }}=\left\{\begin{array}{c}
2 \theta L_{F}\left[(1-\theta) L_{H}+\theta L_{F}\right]^{-1} \\
2(1-\theta) L_{H}\left[(1-\theta) L_{H}+\theta L_{F}\right]^{-1}
\end{array} \text { if } \quad \theta L_{F} \leq(1-\theta) L_{H}\right. \\
G L_{\text {final good } 1}=G L_{\text {final good } 2}=0
\end{gathered}
$$

And, defining the trade-weighted Grubel-Lloyd index as a summary measure of a country's intra-industry trade:

$$
T W G L=\sum_{k}\left[G L_{k} \times\left(\frac{X_{k}+M_{k}}{\sum_{k}\left(X_{k}+M_{k}\right)}\right)\right]
$$

We have:

$$
T W G L=\left\{\begin{array}{llr}
\theta L_{F}\left[(1-\theta) L_{H}+\theta L_{F}\right]^{-1} & \text { if } & \theta L_{F} \leq(1-\theta) L_{H} \\
(1-\theta) L_{H}\left[(1-\theta) L_{H}+\theta L_{F}\right]^{-1} & \text { if } & \theta L_{F} \geq(1-\theta) L_{H}
\end{array}\right.
$$

Hence we can show that, if $\theta L_{F} \leq(1-\theta) L_{H}$, holding world endowment of labour constant:

$$
\left.\frac{d T W G L}{d L_{H}}\right|_{d L_{H}+d L_{F}=0}=-\left.\frac{d T W G L}{d L_{F}}\right|_{d L_{H}+d L_{F}=0}=\frac{-\theta(1-\theta)\left(L_{H}+L_{F}\right)}{\left[(1-\theta) L_{H}+\theta L_{F}\right]^{2}}<0
$$

And, if $\theta L_{F} \geq(1-\theta) L_{H}$ :

$$
\left.\frac{d T W G L}{d L_{H}}\right|_{d L_{H}+d L_{F}=0}=-\left.\frac{d T W G L}{d L_{F}}\right|_{d L_{H}+d L_{F}=0}=\frac{\theta(1-\theta)\left(L_{H}+L_{F}\right)}{\left[(1-\theta) L_{H}+\theta L_{F}\right]^{2}}>0
$$

If $\theta$ is assumed to be equal to 0.5 (expenditure is equally divided between the two final goods), then the interpretation is straightforward. If the Home country is larger than the Foreign country (the first case), the TWGL index is negatively related to Home country size, while the reverse is true if Home is smaller than Foreign (the second case). In other words, the TWGL index is positively related to the size of the smaller of the two countries, and negatively related to the size of the larger of the 
two countries. This of course is the same prediction as in models of trade under imperfect competition, and which has received empirical support elsewhere (see Helpman and Krugman (1985), Helpman (1987), Hummels and Levinsohn (1995)). 


\section{Appendix D: Model based on monopolistic competition}

As noted in the text, one of the objectives of this paper is to show that a model of trade in intermediate and final goods can be developed based on perfect competition, which yields similar results to a model based on monopolistic competition. In this Appendix, we derive the model assuming monopolistic competition in the production of intermediate goods. The results of this model are compared to the model in the text, in Section 4.

Consumer utility takes the same form as equation (1) in the text. The two final goods can be assembled costlessly from the intermediate goods, using the following Constant Elasticity of Substitution (CES) production functions in the two countries:

$$
\begin{array}{ll}
Q_{1 H}=\gamma\left[\sum x_{1 H}^{\rho}+\sum x_{1 F}^{\rho}\right]^{\frac{1}{\rho}} & Q_{2 H}=\left[\sum x_{2 H}^{\rho}+\sum x_{2 F}^{\rho}\right]^{\frac{1}{\rho}} \\
Q_{1 F}=\left[\sum x_{1 H}^{\rho}+\sum x_{1 F}^{\rho}\right]^{\frac{1}{\rho}} & Q_{2 F}=\gamma\left[\sum x_{2 H}^{\rho}+\sum x_{2 F}^{\rho}\right]^{\frac{1}{\rho}}
\end{array}
$$

Where $0<\rho<1$. Each intermediate good is produced by a single firm under monopolistic competition and increasing returns to scale, and the technology for producing intermediate inputs is the same across countries. Following Krugman (1980) and Ethier (1982), labour used in each intermediate input is given by $l_{i}=\alpha+$ $\beta q_{i}$. As is well-known in the literature, assuming symmetry across firms, the equilibrium price and output of each intermediate input and the number of varieties are:

$$
p_{i j}=\frac{\beta w}{\rho} \quad q_{i j}=\frac{\alpha \rho}{\beta(1-\rho)} \quad n_{j}=\frac{L_{j}(1-\rho)}{\alpha}
$$

It was shown in Appendix B that each intermediate input is used in each final good in the following proportions:

$$
x_{1 j}=\theta q_{i j} \quad x_{2 j}=(1-\theta) q_{i j}
$$

In autarky, substituting from (D3) and (D2) into (D1a) the output of the two final goods in Home is:

$$
\begin{aligned}
Q_{1 H} & =\gamma\left[n_{H}\left(\theta q_{i H}\right)^{\rho}\right]^{\frac{1}{\rho}}=\gamma \theta\left[\frac{L_{H}(1-\rho)}{\alpha}\right]^{\frac{1}{\rho}}\left[\frac{\alpha \rho}{\beta(1-\rho)}\right] \\
Q_{2 H} & =\left\{n_{H}\left[(1-\theta) q_{i H}\right]^{\rho}\right\}^{\frac{1}{\rho}}=(1-\theta)\left[\frac{L_{H}(1-\rho)}{\alpha}\right]^{\frac{1}{\rho}}\left[\frac{\alpha \rho}{\beta(1-\rho)}\right]
\end{aligned}
$$

Hence utility per capita under autarky is:

$$
U_{H}^{A}=\left(\frac{Q_{1 H}}{L_{H}}\right)^{\theta}\left(\frac{Q_{2 H}}{L_{H}}\right)^{1-\theta}=\gamma^{\theta}\left[\frac{\alpha \rho}{\beta(1-\rho)}\right]\left[\frac{1-\rho}{\alpha}\right]^{\frac{1}{\rho}}\left[\theta^{\theta}(1-\theta)^{1-\theta}\right]_{H}^{\frac{1-\rho}{\rho}}
$$

Under free international trade, with Home specialising in final good 1 and Foreign in final good 2, the world output of the two final goods is: 


$$
\begin{aligned}
& Q_{1 H}=\gamma\left[\left(n_{H}+n_{F}\right)\left(\theta q_{i H}\right)^{\rho}\right]^{\frac{1}{\rho}}=\gamma \theta\left[\frac{\left(L_{H}+L_{F}\right)(1-\rho)}{\alpha}\right]^{\frac{1}{\rho}}\left[\frac{\alpha \rho}{\beta(1-\rho)}\right] \\
& Q_{2 F}=\gamma\left\{\left(n_{H}+n_{F}\right)\left[(1-\theta) q_{i H}\right]^{\rho}\right\}^{\frac{1}{\rho}}=\gamma(1-\theta)\left[\frac{\left(L_{H}+L_{F}\right)(1-\rho)}{\alpha}\right]^{\frac{1}{\rho}}\left[\frac{\alpha \rho}{\beta(1-\rho)}\right]
\end{aligned}
$$

Hence per capita utility under free trade is:

$$
U_{H}^{F T}=\gamma\left[\frac{\alpha \rho}{\beta(1-\rho)}\right]\left[\frac{1-\rho}{\alpha}\right]^{\frac{1}{\rho}}\left[\theta^{\theta}(1-\theta)^{1-\theta}\right]\left(L_{H}+L_{F}\right)^{\frac{1-\rho}{\rho}}
$$

The gains from trade are given by dividing (D7) by (D5):

$$
G_{H}=\frac{U_{H}^{F T}}{U_{H}^{A}}=\left(\frac{L_{H}+L_{F}}{L_{H}}\right)^{\frac{1-\rho}{\rho}} \gamma^{1-\theta}>1
$$

Similarly to equation (12) in Section 3, there are two components to the gains from trade: that which depends on the larger number of varieties of inputs $\left[\left(L_{H}+L_{F}\right) / L_{H}\right]^{(1-\rho) / \rho}$, and that which depends on comparative advantage $\left(\gamma^{1-\theta}\right)$.

Following the same steps as in Section 3, the value of Home's final good output in free trade is:

$$
P_{1} Q_{1 H}=P_{1} \gamma \theta\left[\frac{\left(L_{H}+L_{F}\right)(1-\rho)}{\alpha}\right]^{\frac{1}{\rho}}\left[\frac{\alpha \rho}{\beta(1-\rho)}\right]
$$

While the value of intermediate inputs used in its production is:

$$
p_{H}\left(n_{H}+n_{F}\right) x_{i H}=p_{H} \theta\left[\frac{\left(L_{H}+L_{F}\right)(1-\rho)}{\alpha}\right]\left[\frac{\alpha \rho}{\beta(1-\rho)}\right]
$$

If there is free entry and exit, then profits are zero, and these two expressions are equal to each other, so setting the price of intermediates $p_{H}=1$ allows us to solve for the relative price of final good 1 :

$$
P_{1}=\left(\frac{1}{\gamma}\right)\left[\frac{\left(L_{H}+L_{F}\right)(1-\rho)}{\alpha}\right]^{1-\frac{1}{\rho}}
$$

The value of final goods exports of Home is, making use of (D6a) and (D11):

$$
\frac{L_{F}}{L_{H}+L_{F}} P_{1} Q_{1 H}=\frac{\rho \theta L_{F}}{\beta}
$$

The value of intermediate goods exports of Home is, making use of $p_{H}=1$ and (D2):

$$
(1-\theta) p_{H} q_{i H} n_{H}=\frac{\rho(1-\theta) L_{H}}{\beta}
$$

Hence, the value of Home's exports of the final good as a share of Home's total exports is:

$$
\theta L_{F}\left[\theta L_{F}+(1-\theta) L_{H}\right]^{-1}
$$

Which is exactly the same expression as equation (23) in the text. 
Figure 1: Scatterplot of consumption goods as a share of total exports against GDP, $2012(N=131)$.

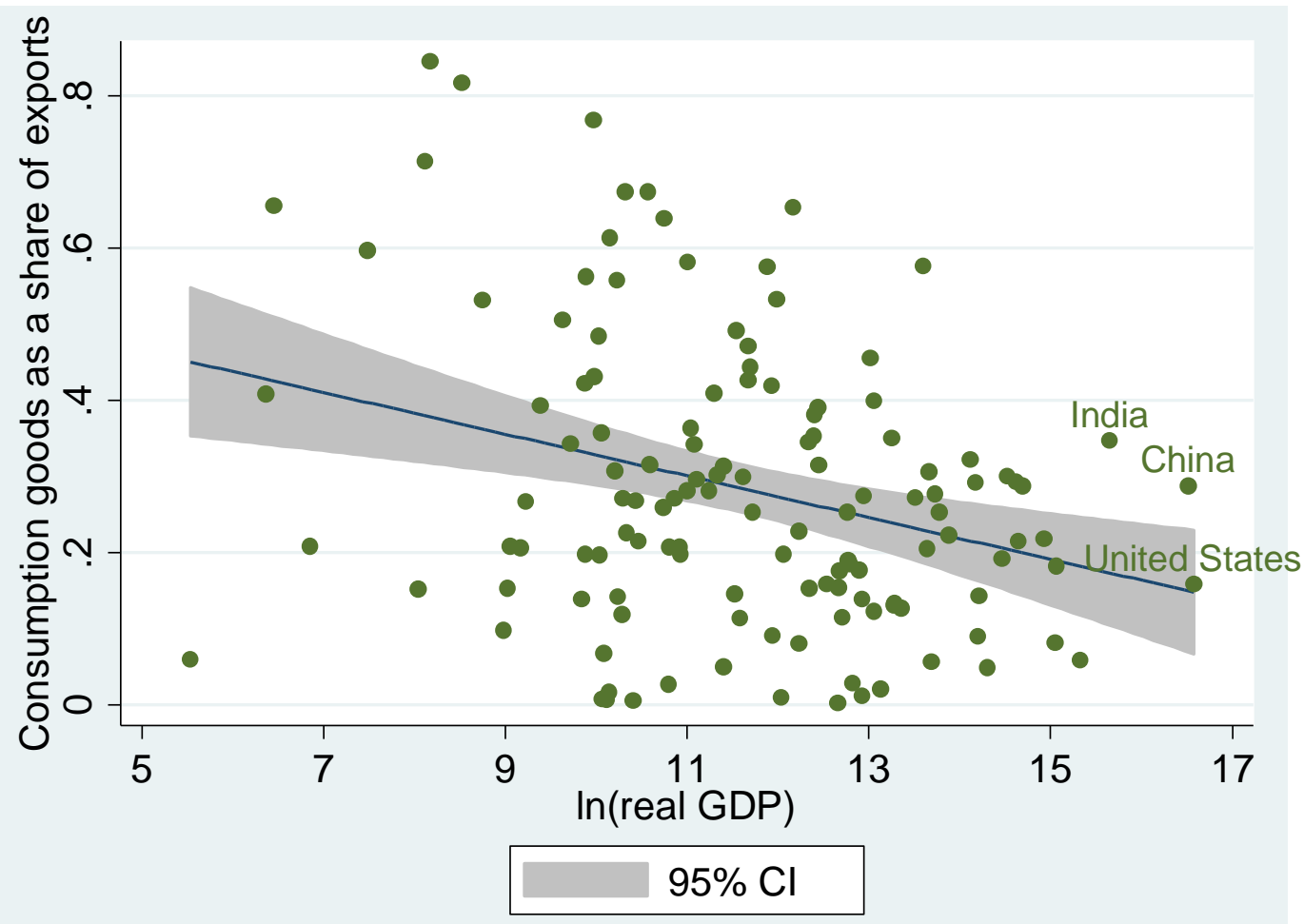

